\title{
Relationship between Students' Personality and Mental Health at University of Guilan (Faculty of Humanities)
}

\author{
Abbas Sadeghi' ${ }^{1}$, Nader Ofoghi' ${ }^{2}$, Setareh Azizi ${ }^{3}$ \\ ${ }^{1}$ Department of Educational Sciences, University of Guilan, Rasht, Iran \\ ${ }^{2}$ Department of Social Sciences, University of Guilan, Rasht, Iran \\ ${ }^{3}$ Department of Psychology, University of Islamic Azad University, Rasht, Iran \\ Email: asadeghi1394@gmail.com, n ofoghi@yahoo.com, setarehazizi@gmail.com
}

Received 10 June 2015; accepted 28 July 2015; published 31 July 2015

Copyright (C) 2015 by authors and Scientific Research Publishing Inc.

This work is licensed under the Creative Commons Attribution International License (CC BY). http://creativecommons.org/licenses/by/4.0/

(c) ()

\section{Abstract}

The main goal of this research was the scrutiny of relationship between students' personality characteristics and mental health at the University of Guilan. The population was the students of the Faculty of Humanities in 2009 with 3000 which 196 were selected using Kerjeci \& Morgan table and stratified sampling method. They answered to the NEO and GHQ questionnaires. Results showed that there was relationship between personality characteristic of neurotic, openness, extraversion and being conscionable with mental health. Meanwhile, openness had the highest and extraversion with the lowest correlation scale and most of students (65\%) had low mental health. Also, there were no significant differences among students with respect to different courses but significant difference with respect to gender and age.

\section{Keywords}

Personality Characteristic, Mental Health, Student, University

\section{Introduction}

Keeping mental and physical health is one of the most important tasks in humans' life. Health and security are two gifts that if human do not lose them will not understand the value of them. Nowadays the subject of mental health is deeply polestar the specialists of behavior and social science. Mental health is the mean of mental thought and purpose is showing the positive situation and mental health that the person could help toward creating a valuable system about the creation of a stimulus, development and integration within individuals, national 
and international. Indeed mental health could help people to choose to create correct methods of mental and emotional health till compatible environment and optimum methods for resolving problems [1]. Most of these studies accepted these relations [2]. These results showed that personality could predict and justify 32 to 56 percentages scores' variant of mental health [3], realized that those people who have more agreement from life, use contrast styles more efficient and proper, experience positive emotions and feelings and have higher general health. This article is searching survey and nomination of the personality characteristic ratio in mental health and increasing this amount among Humanities’ students.

\section{Mental Health Definitions}

Mental health is the prevention of mental illness appearance and wholesome till society's persons can by balance personality and mental make a relationship with environmental ingredients and in the way of securing needs, talents' efflorescening and effort to reach their sublimity individual and social aims [4]. From these introductions for mental health could get a result that Mental Health's goal is prevention and treatment of mental disorder till this person successes in healthy and positive adjustment with self and social environment. Health Global Organization (2001) implied that mental health is a crucial need for improving human's life quality [5]. With the aim of securing optimum life quality, an activity part of psychologists, behavioral science scientists and counselors designated to improving that. Up to now multiple introductions of "Mental Health" has presented that all of them emphasized on the importance of integration and totality.

Mental health as a balance among members and environment in reaching to self-efflorescence [6]. This index emphasizes on health physical, psychological and social dimensions and it seems that it is a separable and clear compass that affected by person's experiences, believes, expectances and feels [7].

\section{The Importance of Mental Health}

In quick and machine world everything is out of balance, speeds are multi doubles, attempts are out time and tired nesses are irrecoverable and mental diseases are outpoint other diseases and poverty, wars, spoils are increasing everyday just spiritual, positive and inner revolution bankroll could reclaim human from these mental separated and unorganized [8]. When mental needs are fulfilled and moral behaviors are shown and human could get far from (his/her) physic and does not feel pain, (he/she) accesses that never experience tension [9] [10]. There is a different concept by work stressors between two organizations with two different profile activities. And also there is a different between meaning of mental and physical hygiene [11]. This survey shows that whatever the positive physical health is more, individual hygiene is more, too. And guidance toward life efficient standards causes management of stress sources in life.

It is a positive augury when hard realities, physic health troubles put a power effect on mental health and this effect attack on social stock and social relationships between people who have health belong feelings [12].

Adjusting gifted and non gifted adults and youth concentrating on personal characteristics in growth approach, finally there are not any meaningful differences in adjustment of young and adult gifted [13].

Four mental health hospital psychiatrists, role and their responsibility, referred and effective system did not clear and they are following the learning and quality theory [14]. Like the other surveys about Histrya and Hypocondriya, there are two factors of characteristics higher than the other personality characteristics and psycho-social factors could put more effects on intention back chronic pain [15]. Benediction with GOD is one of the most meaning full and constructive positive human's aspects and the most basic of human spiritual and developmental factors [16].

Keeping social and physical hygiene is one of the most important tasks in today s humans' life. Islam has some programs for keeping humans' social and physical health till this way could educate people to be faith full and ripen [17] [18]. Today's complexity of life problems is stricken people to conflicts that if will not prevent on time and will not produce mental health basics and tools, undoubtedly it breakouts the psychological and emotional conflicts like body diseases. On the other hand, environmental factors and new life pressers are very important in bringing out psychological diseases and conflicts because everyone In daily views could easily feel that when life is very complex some people may not resolve their problems and finally given diseases. This topic writers are hope full that the results of this survey can create optimum changes in students' mental health and lead them to drawn goals. 
It could be away to program producers to emphasis till in TV programs, films and serials about the importance of religion beliefs specially prays in mental health. And also since our Moslems' beliefs and trusts is depended that Islam's religion as a ideology is introducing the most complete and healthy human's life style and its orders has moral, interpersonal, hygiene and social extend, so it seems the effects and religion's varieties in mental hygiene is a crucial importance to scientific study.

\section{Research Questions}

1) What is the amount of students' mental health?

2) Whether there is a relation between every personality characteristic and the amount of mental health?

3) What kind of personality characteristic has more effective role in mental health?

4) What kind of personality characteristic has less effective role in mental health?

5) Is there any difference about personality characteristic and the amount of mental health by split on gender?

6) Is there any difference about personality characteristic and the amount of mental health by split on age?

7) Is there any difference about personality characteristic and the amount of mental health by split on education tracks?

\section{Research Method}

The method of this research is correlation, because the main goal of the research despite of surveying the relationship between personality characteristics and mental health varieties estimating amount of personality characteristics in mental health.

\section{Population and Sampling}

The research population was all from the students of Faculty of Humanities (about 3000 students) in 2010-2011 academic years. The samples were selected by crystallizing 196 students using Kerjeci and Morgan’s table (1970) and division sampling method. The returned questionnaires number had 175 cases.

\section{Instruments}

NEO-PI-R (LONG FORM) Personality Characteristics Criterion

This research includes 240 original scales which are neurotic, extrovert, openness, acceptance and conscionable. It is emphasized that this questionnaire has initially been built by McCurry and Kusta in 1970 and has been reviewed in 1991. The Persian translation of this test began in 1997 [19]. This test was standardized by Shiraz Education Center in 1998.

\section{Findings}

\section{First Research Question: What is the amount of Mental Health in students?}

Table 1 shows that most of students (65\%) believed that they have low mental health and (35\%) have high mental health.

Second Research Question: Is there any relationship between personality characteristics and mental health?

Table 2 shows that Openness with $r=0 / 244$ have the most coefficient correlation with students' mental health.

Question 3: What kind of personality characteristic has more effective role in mental health?

Question4: What kind of personality characteristic has less effective role in mental health?

Table 1. Frequency students on mental health.

\begin{tabular}{cccc}
\hline Collective percent & Percent & Frequency & yes \\
\hline $\mathbf{5 9}$ & $35 \%$ & $\mathbf{6 1}$ & $\mathbf{1 1 4}$ \\
no & $65 \%$ & $\mathbf{1 7 5}$ & total \\
& $\mathbf{1 0 0}$ & & \\
\hline
\end{tabular}


Table 2. Correlation coefficient between five personality factors and mental health.

\begin{tabular}{|c|c|c|c|c|c|c|}
\hline & & Neurotic & Extroversion & Openness & Agreement & Conscionable \\
\hline \multirow{3}{*}{ Mental health } & $\mathrm{r}$ & ${ }^{*} \mathbf{0} / 135$ & ${ }^{*} 0 / 114$ & ${ }^{*} 0 / 244$ & ${ }^{*} 0 / 181$ & ${ }^{*} 0 / 169$ \\
\hline & Sig & $0 / 05$ & 0/05 & 0/05 & 0/05 & $0 / 05$ \\
\hline & Total & 175 & 175 & 175 & 175 & 175 \\
\hline
\end{tabular}

\section{Question 5: Are there any difference among personality characters and mental health?}

Tables 2-4 confirm that there is a difference meaning among students from personality characteristics and mental health.

Question 6: Is there any difference about personality characters and mental health in education track?

Table 5 shows that the total Mean is lower than 2/50, But Language discipline has a little higher (2/39) and Management discipline has the highest with a little lower Mean (2/22).

For the comments, not all the questions raised in the research questions section are fully discussed in the findings section. To be specific, the two questions "Is there any difference about personality characteristic and the amount of mental health by split on gender?" and "Is there any difference about personality characteristic and the amount of mental health by split on age?” are not addressed in the findings section. Please kindly address them in the findings section.

\section{Summary and Discussions}

By the result of this research there is a positive and direct relation between personality characters neurotic, extroversion, openness, acceptance and conscionable with mental health. The others' result showed this, too. There is a different concept from self by work stressor factors between two organizations with activity profiles. Also there is a difference between mental and physical health. This survey shows whatever physical health is positive, personal health is the same positive and guiding toward efficient life standards causes managing the stress resources in life When hard realities physical health problems put a power effect on mental health and this effect attacks social stock and social relation among those people feeling correct belongings is a positive pre perception in mental health [12].

By these results, there is a positive relation among personality characters, neurotic, extroversion, openness, concord and consciousness. The results of this research are harmonized with some researches [20] that show positive relation of extroversion [2] [3]. There is a negative and counter relation between mental health and neurotic and positive and right relation between extrovert and mental health. In a part of this survey got the same results [21].

Fighting resulted from no agreement with acceptance and compatible of couples handed and decreased their mental health [22].

And also there is a relation with survey there is a relation between extrovert, satisfaction and conscionable characters and giving more help in special neurotic people [23]. Research shows that this relation is positive, too [21]. In elucidating positive relation and mental health could reasoning that people with high score in open thought may be more curious about inside and outside experiences and they enjoy more about new experiences and ideas. It means that they have more imaginary life and more deep thought by shaping their imaginations and use it as an upbringing their creativity. People with these characteristics usually imagine following agitation and favorite thought in their imaginary without decreased factors [19]. These people when encountered with disaster factors as usually and steady and it affected their life, gradually feel repulsion and because no access to their imagines stricken clinical and sick signs. Acceptance and agreement are interring personals' dimension. Harmonized and compatible relations for having and keeping mental health are inevitable.

Also, the results showed that there were no significant differences among students with respect to different courses but significant difference with respect to gender and age. It means that there is a general agreement about relationship between students' personality characteristics and mental health in two different genders and in all age groups. It seems, two factors affected about these results firstly the importance of mental health and second their observations of the reactions of different personalities for example openness personality behaves differently in comparison to nerves one. 
Table 3. Students split on gender.

\begin{tabular}{ccccccc}
\hline & & & Openness & Agreement & conscionable \\
\hline $\begin{array}{c}\text { Mental } \\
\text { health }\end{array}$ & $\mathrm{r}$ & ${ }^{*} 0 / 135$ & $\underline{-\mathbf{0 / 1 1 4}}$ & ${ }^{*} 0 / 244$ & ${ }^{*} 0 / 181$ & ${ }^{*} 0 / 169$ \\
& Sig & $0 / 05$ & $\underline{\mathbf{0 / 0 5}}$ & $0 / 05$ & $0 / 05$ & $0 / 05$ \\
& Total & 175 & $\underline{\mathbf{1 7 5}}$ & 175 & 175 & 175 \\
\hline
\end{tabular}

Table 4. Analysis of variance table.

\begin{tabular}{cccc}
\hline Source & D.F & Sum of squares & Mean squares \\
Between & 1 & 1.2387 & $1.355 .19^{*}$ \\
Within & 174 & 48.2312 & 0.26 \\
Total & 175 & 49.8767 & D.F $=174(P<0.035)^{*}$ \\
Under 20 - 25 with 26-up & & & . \\
\hline
\end{tabular}

Significant $\mathrm{P}<0.05$.

Table 5. Students split on educational disciplines.

\begin{tabular}{|c|c|c|c|c|c|c|c|c|c|c|}
\hline Discipline & M & G & P \& C & LA & LI & P \& L & $F$ & Sig & Eta & Power \\
\hline Mean & $2 / 22$ & $2 / 24$ & $2 / 36$ & 2/39 & $2 / 30$ & $2 / 25$ & $1 / 81$ &.$/ 11$ &.$/ 311$ &.$/ 542$ \\
\hline Standard deviation &.$/ 34$ &.$/ 31$ &.$/ 59$ &.$/ 29$ &.$/ 56$ & /33 & & & & \\
\hline
\end{tabular}

M = Management, G = Geography, P \& C = Psychology and Counseling, LA = Languages, LI = Literature, P \& L = Politic Sciences and Low.

At the end for future inspectors proposed that do science effort scrutinizing the effective factors on mental health deficiency factors and presenting suitable ways for promoting students' mental health in University of Guilan or standard governed or private education institutes.

\section{References}

[1] Hosseini, S.A. (2002) Principles of Mental Health. Shrine Broadcasting Footage Rzavy. Mshahd, Iran.

[2] Chen, Y.-C. (2005) Study of the Relationship of Personality Traits and Job Satisfaction, among Professional Sales Representatives in the Pharmaceutical Industry in Taiwan. Context for Examining Celebrity Worship and Mental Health. British Journal of Psychology, 105-107.

[3] Razavieh, A., Moin, L.B. and Principle, F. (2010) The Role of Personality Traits and Marital Satisfaction Job Satisfaction. Veterans Affairs Shhrshyraz Married Martyr Foundation. Scientific Fslnamh—New Research from Society, in the First Quarter Shmarh, Ss18-1.

[4] Maltaby, J., Day, L., Mccutcheon, L.E., Gillett, R., Houran, J. and Ashe, D.D. (2004) Personality and Coping: A Context for Examining Celebrity Worship and Mental Health. British Journal of Psychology, 95, 411-428. http://dx.doi.org/10.1348/0007126042369794

[5] Mirkamaly, S.M. (1998) Mental Health in Chools. Journal of Management.

[6] World Health Organization (2001) Mental Health: New Understanding, New Hope. The World Health Report. World Health Organization, Geneva.

[7] Kaplan, E. and Sadvk, B. (1994) Synopsis of Psychiatry, Clinical Psychiatry and Behavioral Sciences. Pvrafkary Translation, Free Publication, Tehran.

[8] Khosravi, Z. (1999) Ment or Health or Mental Disorder. Train No. 10.

[9] Shafee, A. (1995) Proceedings of the Seminar and Consulting, Allameh Taba Tabaeei University, Iran.

[10] Steinmo, S., Hagger-Johnson, G. and Shahab, L. (2014) Bidirectical Association between Mental Health and Physical Activity in Older Adults. Preventive \& Medicine, 66, 74-79.

[11] Mahini, F., Yahyaei, D. and Foroushani, Z.J. (2012) The School Role in Lively Education and Student's Mental Health. Procedia - Social and Behavioral Sciences, 47, 1408-1412. 
[12] Jones, R., Heim, D., Hunter, S. and Ellaway, A. (2014) The Relative Influence of Neighbourhood Incivilities Cognitive Social Capital, Club Membership and Individual Characteristics on Positive Mental Health. Health and Place, 28, 187 193. http://dx.doi.org/10.1016/j.healthplace.2014.04.006

[13] Ramzi, S., Pakdaman, S. and Fathabadi, J. (2011) The Developmental Study of Adjustment in Gifted and Nongifted Adolescents and Youth Regarding Personality Characteristics. Social and Behavioral Sciences, 30, 43-47.

[14] Almoshawah, S.A. (2010) An Evaluation of Psychiatrist View towards the Mental Health Services in Saudi Arabia. Journal of Taibah University Medical Sciences, 5, 36-48. http://dx.doi.org/10.1016/s1658-3612(10)70122-0

[15] Tavalaii, A., Kargar, K.H., Farzanegan, G.H., Saeid, S.Y. and Radfar, S. (2010) Personality Characteristic of Patients with Chronic Low Back Pain. Social and Behavioral Sciences, 5, 372-376.

[16] Mousavi, L., Mary, S., Gholamrezayee, S., Head, F. and Manners, F. (2010) The Role of Mental Health and Spiritual Health of Humans. Journal of Epidemiology and Tndrsty, vyzhh of a Congress, 204-204.

[17] Ahmadi, A.A. (1988) Illness and Mental Health. Mahnameh Cultured Upbringing Persian Date Aban.

[18] Gatab, T.A. and Pirhayati, S. (2012) The Effect of the Selected Exercise on Male Students' Happiness and Mental Health. Social and Behavioral Sciences, 46, 2702-2705.

[19] Fard, M.H., Zivdar, M. and Prince, R.G.H. (2006) Evaluation of Pressure Drop and Mass-Transfer Characteristics of a Structured Packing for Production and Separation of Food Flavours: Part II: Mass-Transfer Characteristics. Food and Bioproducts Processing, 84, 206-212.

[20] Whishman, M.A., Uebelacker, L.A. and Weinstock, L.M. (2004) Psychopathology and Marital Satisfaction. Journal of Consulting and Clinical Psychology, 72, 830-838. http://dx.doi.org/10.1037/0022-006X.72.5.830

[21] Jafarnejad, P., et al. (2004) Investigated the Relationship between the Big Five Personality, Coping Styles and Mental Health of Undergraduates. Journal of Psychology, 74-51.

[22] Kulik, L. (2006) Personality Profiles, Life Satisfaction and Gender-Role Ideology Adult Marital Adjustment. Personality and Individual Differences, 38, 519-531.

[23] Seekles, W.M., Cuijpers, P., Van de ven, P., Penninx, B.W.J.H., Verhaak, P.F.M., Beekman, A.T.F. and van Straten, A. (2012) A Personality and Perceived Need for Mental Health Care among Primary Care Patients. Journal of Affective Disorders, 136, 666-674. 